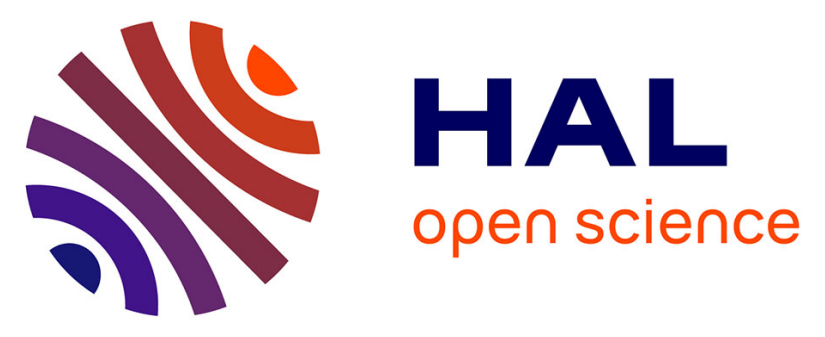

\title{
Preharvest UV-C radiation influences physiological, biochemical, and transcriptional changes in strawberry cv. Camarosa
}

Isadora Rubin de Oliveira, Giseli Rodrigues Crizel, Joseana Severo, Catherine M.G.C. Renard, Fabio Clasen Chaves, César Valmor Rombaldi

\section{To cite this version:}

Isadora Rubin de Oliveira, Giseli Rodrigues Crizel, Joseana Severo, Catherine M.G.C. Renard, Fabio Clasen Chaves, et al.. Preharvest UV-C radiation influences physiological, biochemical, and transcriptional changes in strawberry cv. Camarosa. Plant Physiology and Biochemistry, 2016, 108, pp.391-399. 10.1016/j.plaphy.2016.08.012 . hal-02634851

\section{HAL Id: hal-02634851 \\ https://hal.inrae.fr/hal-02634851}

Submitted on 27 May 2020

HAL is a multi-disciplinary open access archive for the deposit and dissemination of scientific research documents, whether they are published or not. The documents may come from teaching and research institutions in France or abroad, or from public or private research centers.
L'archive ouverte pluridisciplinaire HAL, est destinée au dépôt et à la diffusion de documents scientifiques de niveau recherche, publiés ou non, émanant des établissements d'enseignement et de recherche français ou étrangers, des laboratoires publics ou privés. 


\section{Graphical Abstract}

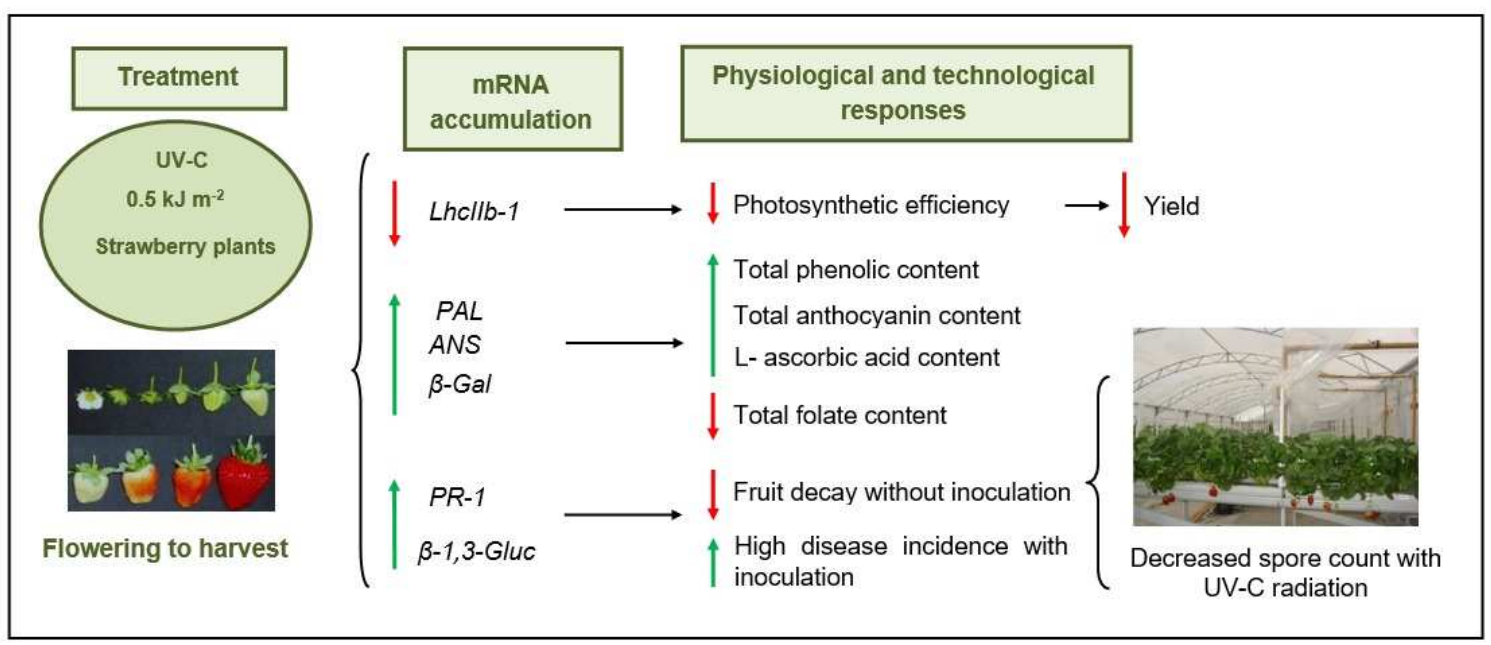


1 Preharvest UV-C radiation influences physiological, biochemical, and transcriptional

2 changes in strawberry cv. Camarosa

3

4 Isadora Rubin de Oliveira ${ }^{a^{*}}$, Giseli Rodrigues Crizel ${ }^{\mathrm{b}}$, Joseana Severo ${ }^{\mathrm{c}}$, Catherine M.G.C.

5 Renard $^{\mathrm{d}, \mathrm{e}}$, Fabio Clasen Chaves $^{\mathrm{b}}$, Cesar Valmor Rombaldi ${ }^{\mathrm{b}}$

6

7

8 âUFel, Universidade Federal de Pelotas, CDTec, Programa de Pós-graduação em

9 Biotecnologia, C.P. 354, CEP 96010-000, Pelotas, RS, Brazil.

$10{ }^{\mathrm{b}}$ UFPel, Universidade Federal de Pelotas, FAEM, Departamento de Ciência e Tecnologia

11 Agroindustrial, Programa de Pós-graduação em Ciência e Tecnologia de Alimentos, C.P. 354,

12 CEP 96010-900, Pelotas, RS, Brazil.

13 ' $\mathrm{IFF}$, Instituto Federal Farroupilha, Eixo de Produção Alimentícia, Rua Fábio João Andolhe,

14 1100, Bairro Floresta, CEP 98590-000, Campus Santo Augusto, Santo Augusto, RS, Brazil.

$15{ }^{\mathrm{d}}$ INRA, UMR408 Sécurité et Qualité des Produits d'Origine Végétale, F-84000 Avignon,

16 France

17 eAvignon University, UMR408 Sécurité et Qualité des Produits d'Origine Végétale, F-84000

18 Avignon, France

19

20

$21 *$ Corresponding author. Tel./fax: +55 5332757284 .

22

E-mail address: isarubin@gmail.com 


\section{Abstract}

24 Ultraviolet C (UV-C) radiation is known for preventing fungal decay and enhancing 25 phytochemical content in fruit when applied postharvest. However, limited knowledge is 26 available regarding fruit responses to preharvest application of UV-C radiation. Thus, the 27 effects of UV-C radiation on photosynthetic efficiency, dry matter accumulation and 28 partitioning, fruit yield and decay, phytochemical content, and relative transcript accumulation of genes associated with these metabolic pathways were monitored in strawberry (Fragaria x ananassa Duch.) cv. Camarosa. A reduction in photosynthetic

31 efficiency was followed by a decrease in light harvesting complex LhcIIb-1 mRNA 32 accumulation as well as a decrease in yield per plant. Phenylalanine ammonia lyase activity, 33 phenolic, anthocyanin, and L-ascorbic acid contents were higher in UV-C treated fruit. In 34 addition, preharvest UV-C treatment reduced microorganism incidence in the greenhouse and 35 on the fruit surface, increased the accumulation of $\beta-1,3-G l u c$ and $P R-1 \mathrm{mRNA}$, and prevented fruit decay.

38 Keywords: Fragaria $\mathrm{x}$ ananassa Duch.; abiotic stress; antioxidants; gray mold disease. 


\section{Introduction}

Strawberry (Fragaria $\times$ ananassa Duch.) pseudo fruit, henceforth named fruit, is rich in bioactive compounds, such as L-ascorbic acid, folates, and phenolic compounds including anthocyanins (Giampieri et al., 2015; Tulipani et al., 2011). This fruit is characterized by high respiration and transpiration rates, low mechanical resistance, and high susceptibility to gray mold caused by Botrytis cinerea (Neri et al., 2014). In order to control gray mold, seasonal spraying of fungicides is carried out during fruit development, and postharvest fruit are cold stored under modified atmosphere (Barrios et al., 2014; Feliziani et al., 2015). However, the use of fungicides poses significant health risks to consumers, and demand for strawberries produced with fewer fungicides is increasing (Feliziani et al, 2015).

Alternative control methods that do not leave residues, such as postharvest UV-C radiation, have been shown to prevent decay and improve fruit quality (Baka et al., 1999; González-Aguilar et al., 2007; Maharaj et al., 1999; Severo et al., 2015a, 2015b). In response to postharvest UV-C, tomato fruit developed biochemical and physical barriers against Botrytis cinerea growth by accumulating phenolic compounds, defense proteins, and developing fruit surface modifications (Charles et al., 2008a, 2008b, 2008c). Additionally, it has been reported that postharvest UV-C radiation induces secondary metabolites production that protect fruit against abiotic and biotic stresses (Pombo et al., 2011). Furthermore, these metabolites (phenolic compounds, anthocyanins, carotenoids) also play an important role in fruit quality with impact on human health (Giampieri et al., 2015).

On the other hand, few studies have investigated preharvest UV-C application, and the mechanism of action preventing decay and improving fruit quality is not well understood. Tomato fruit on the vine treated with UV-C showed delayed ripening and inhibition of Penicillium digitatum growth (Obande et al., 2011). The effects of preharvest UV-C on bioactive compounds content in strawberries appears to be cultivar dependent (Xie et al., 
2015). In addition, excess UV-B and UV-C radiation during growth of Arabidopsis thaliana has deleterious effects on plant cells, including DNA damage and oxidation of cellular components with consequent deleterious effects on photosynthesis, phenolic metabolism, carotenoid biosynthesis, and antioxidant defense (Booij-James et al., 2000; Xie et al., 2012). Therefore, the effects of preharvest UV-C treatment on a set of quality parameters including microorganism occurrence and fruit decay, photosynthetic efficiency, dry matter partitioning, yield, phytochemical accumulation, and relative transcript accumulation of genes putatively associated with these metabolic pathways in strawberry were monitored.

\section{Material and methods}

2.1 Plant material and sampling procedure

The experiment was conducted in two greenhouses $(8 \times 12 \mathrm{~m})$ oriented in a northsouth direction and covered with low-density polyethylene film $(200 \mu \mathrm{m})$. Eight hundred seedlings of strawberry cultivar Camarosa were grown according to a crop system described by Portela et al. (2012). Four hundred seedlings were designated for control without UV-C application and the other four hundred for UV-C treatments. This cultivar was chosen due to its vigorous growth habit. The spacing used was $30 \mathrm{~cm}$ between plants and $40 \mathrm{~cm}$ between rows. All plants were fertilized following guidelines described by Sonneveld and Straver (1999) with electrical conductivity (EC) adjusted to $1.5 \mathrm{dSm}^{-1}$. When a variation greater than $10 \%$ of the EC was observed, nutrient or water was added, while $\mathrm{pH}$ was maintained between 5.5 and 6.5. During the $45 \mathrm{~d}$ after transplantation (from May $7^{\text {th }}$ to June $22^{\text {nd }}$ ) all flowers were removed until plants had between ten and twelve leaves. Thereafter, typical cultural practices were followed, and upon development of flower buds (starting July $22^{\text {nd }}$ ) two Jataí (Tetragonisca angustula) bees' boxes were installed for pollination. 
Fruit were harvested during the highest productivity period, which corresponded to the

89 $45^{\text {th }}$ and $85^{\text {th }}$ day after treatments were initiated. Each day, thirty fruit from each treatment were harvested and divided into groups of 10 fruit, each group constituting a replicate. PAL enzyme activity and physicochemical characterization were determined from fruit kept at $80^{\circ} \mathrm{C}$. Total mesophilic bacteria and incidence of fungal decay were determined in fruit harvested at $56 \mathrm{~d}$ after treatments were initiated. The fungal inocula present in the greenhouse air was quantified during the production cycle $(8,32,56$, and $80 \mathrm{~d}$ after treatments were initiated). Real time PCR (qPCR) analyses were carried out from leaves and fruit harvested at $0,8,32,56$, and $80 \mathrm{~d}$ after treatments. At the end of the crop cycle, five plants from each replicate were harvested and fruit, roots, stolons, and leaves were separated to obtain dry matter partitioning. Experiment timeline, showing crop cycle, UV-C treatment, and sampling dates for analysis is presented in Figure 1.

\subsection{UV-C treatment}

The radiation source consisted of four germicidal bulbs (Phillips® ${ }^{\circledR}$ TUV 30 watts/G30T8) emitting light at $254 \mathrm{~nm}$. Plants were placed one meter away from the bulbs. Irradiation was applied from flowering until the last harvest day (July $22^{\text {nd }}$ to November $15^{\text {th }}$ ). Each irradiation application lasted $2 \mathrm{~min}$ and plants received $0.5 \mathrm{~kJ} \mathrm{~m}^{-2}$ (UV light meter, Model 232-RS-203 MRUR, Instrutherm) at 7 PM every four days, totaling 28 applications (Fig. 1). UV-C dose and application intervals were established from exploratory tests using 0 $\mathrm{kJ} \mathrm{m}^{-2}$ to $1.5 \mathrm{~kJ} \mathrm{~m}^{-2}$. Just prior to each UV-C application, bees' boxes were closed and removed from the greenhouses. Control plants did not receive UV-C application.

2.3 Leaf gas exchange and chlorophyll fluorescence analysis 
$\mathrm{CO}_{2}$ assimilation rate $\left(A ; \mu\right.$ molm $\left.{ }^{2} \mathrm{~s}^{-1}\right)$, stomatal conductance $\left(g s ; \mathrm{nmolm} \mathrm{s}^{-1}\right)$, and intracellular $\mathrm{CO}_{2}$ concentration $\left(\mathrm{C} i\right.$; $\mu$ molmol air $\left.^{-1}\right)$ of leaves were monitored with a portable gas exchange system infrared gas analyzer (IRGA, Heinz Walz GmbH, GFS 3000 model). Measurements were performed after the beginning of UV-C treatment (July $22^{\text {nd }}$ ) following the procedure described by Kadir and Sidhu (2006). Chlorophyll fluorescence rate $(F v / F m)$ was measured using the same equipment (Hüther et al., 2013). Evaluation of chlorophyll fluorescence rate was carried out at eight-day intervals (between 9:30 and 11:00 PM), starting two days before the first UV-C treatment (Fig. 1).

2.4 Dry matter partitioning, fruit yield, and physicochemical characterization

At the end of the crop cycle, five plants from each replicate were collected and fruit, roots, stolons, and leaves were separated to obtain dry matter partitioning after drying at $70^{\circ} \mathrm{C}$ for $3 \mathrm{~d}$. Soluble solids (SS) content was determined by refractometry and expressed as ${ }^{\circ}$ Brix. Total acidity (TA) was determined by titration and expressed as mg citric acid per $\mathrm{kg}^{-1}$ of fresh fruit. Fruit color was measured using a colorimeter as described by Severo et al. (2015a). Firmness was evaluated as described by Severo et al. (2015b).

\subsection{Microorganism occurrence}

In order to evaluate the fungal inocula present in the air of the greenhouse a passive sampling was carried out. Petri plates $9 \mathrm{~cm}$ in diameter $\left(0.006359 \mathrm{~m}^{2}\right.$ area $)$ containing greenhouse, ten open plates were placed among the plants for $1 \mathrm{~h}$ at four intervals throughout the production cycle $(8,32,56$, and $80 \mathrm{~d}$ after treatments were initiated). Plates were

135 incubated for $48 \mathrm{~h}$ at $25^{\circ} \mathrm{C}$, and results were expressed as colony forming units (CFU) $\mathrm{m}^{2} \mathrm{~h}^{-1}$. 
137

138

139

140

141

142

143

144

145

146

147

148

149

150

151

152

153

154

155

156

157

158

159

160

161

sterile peptone water, and a one $\mathrm{mL}$ aliquot was inoculated in total plate count agar (PCA) (Sigma-Aldrich 70152). Plates were incubated at $35^{\circ} \mathrm{C}$ for $48 \mathrm{~h}$ and the results were expressed as CFU $\mathrm{g}^{-1}$. To evaluate the incidence of fungal decay, strawberries were stored in plastic boxes and kept at room temperature $\left(\mathrm{RT}, 23 \pm 2{ }^{\circ} \mathrm{C}\right)$ and a relative humidity (RH, $85 \pm 5 \%$ ) for $3 \mathrm{~d}$ after harvest. Results were expressed in percentage (\%) of decayed fruit. In order to assess possible induction of disease resistance, a Botrytis cinerea strain was isolated from diseased strawberry fruit and cultured on potato dextrose agar (PDA) (Sigma Aldrich 70139). As soon as mycelial growth was evident, an agar plug was sub cultured on PDA until spore production occurred. After $7 \mathrm{~d}$ the Petri dish was flooded with sterile water containing $0.02 \%(\mathrm{v} / \mathrm{v})$ Tween 20, filtered and diluted to a concentration of $10^{4}$ spores per mL. After harvest, a portion of the fruit was disinfected $\left(\mathrm{NaClO}, 100 \mu \mathrm{g} \mathrm{L}^{-1}, \mathrm{pH}\right.$ 5.0) for $2 \mathrm{~min}$. Strawberries were wounded $(2 \mathrm{~mm})$ with a sterile probe, one wound per fruit, in the equatorial zone and $20 \mu \mathrm{L}$ of a suspension containing $10^{4}$ Botrytis cinerea spores per $\mathrm{mL}$ water were inoculated. After inoculation, fruits were stored at RT for $3 \mathrm{~d}$ and results were expressed in $\%$ of decayed fruit. This method was adapted from Pombo et al. (2011).

2.6 Phenylalanine ammonia lyase activity (PAL; EC 4.3.1.24)

PAL enzyme activity was determined by homogenizing fifteen grams of fresh tissue in $15 \mathrm{~mL}$ of buffer containing: $20 \mathrm{mM} \beta$-mercaptoethanol (Sigma Aldrich M3148), $0.1 \mathrm{M}$ sodium borate buffer with $\mathrm{pH} 8.8$, and $5 \%(\mathrm{~m} / \mathrm{v})$ of polyvinylpyrrolidone (PVP) (Sigma Aldrich PVP40). After filtration, the homogenate was centrifuged at $12.000 \times \mathrm{g}$ for $20 \mathrm{~min}$. Enzyme activity was measured by adding $1 \mathrm{~mL}$ of the crude enzyme preparation to a reaction medium containing $1 \mathrm{~mL}$ of $0.2 \mathrm{M}$ sodium borate buffer with $\mathrm{pH} 8.8$, and $1 \mathrm{~mL}$ of $0.1 \mathrm{M} \mathrm{L-}$ phenylalanine. After incubation for $1 \mathrm{~h}$ at $30^{\circ} \mathrm{C}$, the reaction was stopped by adding $0.1 \mathrm{~mL}$ of $6 \mathrm{~N} \mathrm{HCl}$ and the absorbance was determined at $290 \mathrm{~nm}$ at intervals of $20 \mathrm{~min}$ for at least one 
162

163

164

165

166

167

168

169

170

171

172

173

174

175

176

177

178

179

180

181

182

183

184

185

hour after the addition of phenylalanine. Enzyme activity was calculated using the molar extinction coefficient of $10^{4} \mathrm{mM}^{-1} \mathrm{~cm}^{-1}$ and expressed in mmol of cinnamic acid $\min ^{-1} \mathrm{~g}^{-1}$ (Zucker, 1965).

2.7 Phytochemical content and antioxidant potential Total phenolic content was determined using the Folin-Ciocalteau reagent (Sigma Aldrich F9252). Total anthocyanin content was determined by extraction using ethanol ( $\mathrm{pH} 1$ ) and antioxidant potential was determined using the ABTS radical scavenging assay. Total phenolic, total anthocyanin, and antioxidant potential analyses were performed as described by Severo et al. (2015b). L-ascorbic acid content was determined spectrophotometrically following Stevens et al. (2006). Folate content was determined by HPLC-UV based on a method described by Delchier et al. (2012). Results were expressed on a fruit fresh weight basis (ffw).

2.8 RNA extraction, cDNA synthesis, and qPCR

Total RNA extraction, RNA quality evaluation, reverse transcription, and qPCR were performed following the protocols used by Severo et al. (2015b). Six genes were chosen based on putative roles in strawberry photosynthesis, defense responses, and phytochemical content: photosynthesis - light harvesting complex (LhcIIb-1) (Xu et al., 2012), defense responses - $\beta$-1,3-glucanase $(\beta-1,3-G l u c)$ and pathogenesis-related protein 1 (PR-1) (Pombo et al., 2011) and phytochemical content - phenylalanine ammonia lyase (PAL) (Galli et al., 2014), anthocyanin synthase (ANS) (Severo et al., 2015b), and $\beta$-galactosidase ( $\beta$-Gal) (Severo et al., 2015a, 2015b). The histone H4 (HIDTH4) was used as an internal standard due to its expression stability under the experimental conditions (Galli et al., 2014). Leaves and 
186

187

188

189

190

191

192

193

194

195

196

197

198

199

200

201

202

203

204

205

206

207

208

209

210

fruit collected from control strawberries plants were used as baseline expression to establish the relative transcript accumulation.

2.9 Experimental design and statistical analysis

The experiment was carried out in a completely random design with three replicates using control plants without UV-C application (greenhouse 1) and plants treated with UV-C (greenhouse 2). Data were analyzed for normality using a Shapiro-Wilk test, for homoscedasticity using a Hartley test, and an analysis of variance (ANOVA) was conducted $(\alpha=0.05)$. A post-hoc analysis was performed using a t-test $(\alpha=0.05)$. Percent data was normalized before statistical analysis.

\section{Results}

3.1 Photosynthetic efficiency, dry matter partitioning, yield, and basic composition

The application of UV-C radiation $\left(0.5 \mathrm{~kJ} \mathrm{~m}^{-2}\right)$ during cultivation resulted in the reduction of $\mathrm{CO}_{2}$ assimilation $(A)$, stomatal conductance $(g s)$, and intracellular $\mathrm{CO}_{2}$ concentration $(\mathrm{C} i)$ of strawberries leaves on average $44 \%, 27 \%$, and $49 \%$, respectively (Figs.

2A, B, C). A significant reduction was also observed for chlorophyll fluorescence rate $(F v / F m)$ (Figs. 2D, E), indicating a possible effect of UV-C on photosystem II. UV-C radiation during cultivation reduced leaf biomass by $28 \%$ and fruit yield by $20 \%$. Root, stolon, and fruit dry matter content were not affected (Figs. 2F, G, H). Although UV-C treated fruit showed lower ${ }^{\circ} \mathrm{Hue}$ (control $32.3{ }^{\circ} \mathrm{Hue}, \mathrm{UV}-\mathrm{C} 30.2{ }^{\circ} \mathrm{Hue}$ ), acidity (control 8.0, UV-C 7.5 in citric acid equivalent $\mathrm{g} 100^{-1} \mathrm{~g} \mathrm{ffw}$ ) and flesh firmness (control $3.45 \mathrm{~N}$, UV-C $3.48 \mathrm{~N}$ ) were not affected.

\subsection{UV-C effect on microorganisms}


212 (Fig. 3A). Mesophilic microorganism count on the surface of strawberries was lower in fruit 213 treated with UV-C (600 CFU.g $\left.{ }^{-1}\right)$ than in control fruit $\left(1670 \mathrm{CFU} \cdot \mathrm{g}^{-1}\right)$ (Fig. 3B). The 214 occurrence of spontaneous decay on strawberries maintained at room temperature for $3 \mathrm{~d}$ was 215 lower in UV-C treated fruit (39\%) than control strawberry (76\%) (Fig. 3C). However, when 216 fruit were inoculated with Botrytis cinerea spores, high levels of decay were detected for both 217 treatments (86\% and $87 \%$ for UV-C and control, respectively), after three days at RT (Fig. $2183 \mathrm{D})$.

3.3 Phytochemical content

PAL enzyme activity increased by $18 \%$ in fruit treated with UV-C (Fig. 4A). Total

222 phenolic, total anthocyanin, L-ascorbic acid content, and antioxidant potential (Figs. 4B, C,

223 D, E, F) were higher in UV-C treated fruit $(43 \%, 22 \%, 9 \%, 39 \%$, respectively), while total 224 folate content was reduced (11\%).

The expression profile of control and UV-C treated plants was similar in leaf and fruit tissues (Fig. 5). Photosynthesis-associated gene LhcIIb-1 encoding for a light-harvesting complex was down-regulated by UV-C while $\beta$-1,3-glucanase $(\beta-1,3-G l u c)$, pathogenesisrelated protein $1(P R-1)$, and phenylalanine ammonia lyase $(P A L)$ were up-regulated by UVC. Anthocyanin synthase $(A N S)$ and $\beta$-galactose dehydrogenase $(\beta-G a l)$ gene expression showed no clear pattern. 


\section{Discussion}

Postharvest UV-C radiation application increases fruit shelf life, affects phytochemical content, and interferes with ripening, maturation, and senescence processes (Baka et al., 1999; Charles et al., 2008a, 2008b, 2008c; González-Aguilar et al., 2007; Maharaj et al., 1999; Pombo et al., 2011; Severo et al., 2015a, 2015b). Few studies have investigated the effects of UV-C radiation application during cultivation (Obande et al., 2011; Xie et al., 2015). In this study, photosynthetic efficiency, dry matter partitioning, fruit yield and decay, phytochemical content, and relative transcript accumulation of genes putatively associated with photosynthesis, defense responses, and phytochemical biosynthesis were monitored in strawberries plants treated with UV-C radiation during cultivation. UV-C radiation had a negative effect on leaf photosynthetic efficiency, reducing $\mathrm{CO}_{2}$ assimilation rate $(A)$, stomatal opening ( $g s)$, and intercellular $\mathrm{CO}_{2}$ concentration ( $\mathrm{Ci}$ ) (Figs. 2A, B, C). A fluorescence parameter $F_{o}$ measurement was taken when all photosystem reaction centers were opened (plants and leaves in the dark) and a fluorescence parameter $F_{m}$ measurement was taken when all reaction centers were closed (maximum light) (Gurunani et al., 2015; Hürther et al., 2013; Zivcak et al., 2014). High $F v / F m$ values indicate high photosynthetic efficiency, and therefore an increase in dry matter content is expected (Goltsev et al., 2009; Gurunani et al., 2015; Zivcak et al., 2014). However, strawberry plants treated with UV-C showed a decrease in $F V=F m-F_{o}$ and $F v / F m$ parameters, as well as a decrease in leaf dry matter content (Figs. 2D, E, F). Concurrently, gene transcript accumulation of LhcIIb-1 decreased in leaves and fruit of UV-C treated plants, confirming the impact of this abiotic stress on photosynthetic parameters. Topcu et al. (2015) observed that UV radiation (280-315 nm) during broccoli growth promoted a decrease in total carotenoid, chlorophyll a, and chlorophyll b contents, but an increase in ascorbic acid, total phenolic, and flavonoid contents. 
Photosynthesis is a multi-step process with successive redox reactions in which

261

photosystem II - light-harvesting complex (PSII - LhcII) is responsible for the absorption of light energy (photons) by chlorophyll molecules (Gurunani et al., 2015). Under abiotic stress conditions, reactive oxygen species (ROS) generated in chloroplasts lead to photoinhibition of PSII-LhcII (Chen et al., 2012). According to Tikkanen et al. (2014), when light energy absorbed by the PSII-LhcII pigments is higher than the energy consumed severe damage to PSII may occur. Therefore, a down-regulation of LhcIIb-1 in plants treated with UV-C may have been a plant defense strategy against possible damage to the photosynthetic machinery. In addition, root, stolon, and fruit dry matter contents were not affected by preharvest UV-C treatment (Fig. 2F) despite the reduction in fruit yield (20\%) (Figs. 2G, H).

Strawberry is highly susceptible to gray mold disease caused by Botrytis cinerea (Neri et al., 2014). Fruit from strawberry plants treated with UV-C during cultivation showed lower incidence of fungal decay (39\%) when compared to untreated strawberries $(76 \%)$. In order to further understand the cause of the decreased decay promoted by UV-C application, the inocula present in the air of the greenhouses and the microbial count on fruit surface were monitored. In addition, strawberry fruit was also inoculated with Botrytis cinerea spores. UVC radiation promoted a disinfectant action in both the greenhouse environment and the fruit surface (Figs. 3A, B, C), and increased transcript accumulation of defense response genes $\beta$ 1,3-Gluc and PR-1. These events combined likely contributed to the lower occurrence of fungal decay in strawberry treated with UV-C radiation before inoculation with Botrytis cinerea spores. However, it is known that gene expression does not always lead to physiological responses, since many post-transcriptional and post-translational events may occur which interfere with the outcome (Mazzucotelli et a., 2008). In addition, strawberry resistance to a variety of pathogens has been reported to be mostly polygenic and quantitatively inherited (Lewers et al., 2003). In general, a plant defense system is composed 
of cell wall structural components, phytochemicals, and PR-proteins (Amil-Ruiz et al., 2011).

Thus it becomes difficult to attribute an inhibition of fungal decay only to an increase of $\beta$ 1,3-Gluc and PR-1 transcripts, since all components of the plant defense system may synergistically be playing a role in inhibition of fungal decay (Amil-Ruiz et al., 2011). Moreover, a reduction in spore and bacterial count upon UV-C radiation was evident. In the present study, inoculation of fruit with Botrytis cinerea spores led to high disease symptom development in both control and UV-C treated fruit (85\%) (Fig. 3D). This result differed from previous reports that showed a reduction of fruit decay by UV-C radiation after inoculation with Botrytis cinerea spores (Pombo et al. 2011; Charles et al. 2008a, 2008b, 2008c). However, the treatment used in the previously mentioned studies was a strong single dose of UV-C, applied to fruit postharvest. In the present study, weaker doses of UV-C radiation were applied from flowering to harvest, constituting a different stress condition. In addition, Botrytis cinerea spore inoculation by wounding of the fruit surface may represent an extreme situation, whereby even the strongest defense system may not be able to counteract.

The relationship between plant and pathogen, and an induction of the plant defense system by biotic and abiotic stresses appear to be quite complex and are not fully understood (Amil-Ruiz et al., 2011). Several authors have observed that cell wall thickness and softening are correlated with pathogen resistance (Cantu et al., 2008; Guidarelli et al., 2011). Furthermore, the effect of postharvest UV-C radiation on fruit cell wall modification and flesh firmness has also been shown (Baka et al., 1999; Maharaj et al., 1999; Charles et al., 2008b, 2008c). In this study, no difference in flesh firmness or fruit decay incidence after inoculation with Botrytis cinerea spores were observed between control and UV-C treated strawberries.

After pathogen inoculation, signaling and metabolic changes due to cell wall injury and pathogen perception may occur (Amil-Ruiz et al., 2011; Neri et al., 2014). Depending on fruit ripening stage, innate immunity, pre-formed mechanical barriers, and a response of 
310

311

312

313

resistance induction, the fruit would be able to counteract the disease (Amil-Ruiz et al., 2011). However, Neri et al., (2014) showed that after inoculation, the physical injury of tissues creates significant changes in strawberry volatiles emission that stimulated Botrytis cinerea growth compared to intact fruit. In the present study, strawberry was submitted to a stress condition from flowering to harvest, in addition to inoculation by wounding the fruit surface, which likely accelerated fruit metabolism resulting in high incidence of gray mold disease.

On the other hand, UV-C treatment during cultivation promoted antioxidant metabolism (Fig. 4). Plants exposed to abiotic stress conditions have increased ROS content, which in turn can cause photoinhibition of the photosynthesis photosystem II repair process (Gurunani et al., 2015; Lemoine et al., 2010). To cope with this stress condition, plants synthesize ROS-scavenging enzymes and antioxidants, such as $\alpha$-tocopherol, L-ascorbic acid, carotenoids, and phenolic compounds that can reduce the rate of photoinhibition (Gill and Tuteja, 2010; Gurunani et al., 2015). In this study however, an increase in phytochemical content was accompanied by a decrease in yield, probably due to the stress condition generated by UV-C application from flowering to harvest. Folate content was also lower in UV-C treated fruit. Since many phenolic compounds and folate are derived from the shikimate pathway with common intermediates such as chorismate, it is plausible that UV-C directed one pathway instead of another (Bekaert et al., 2008).

Preharvest application of UV-C radiation on strawberries from flowering to harvest increased phenylalanine ammonia lyase activity, phenolic compounds, including anthocyanins, L-ascorbic acid, and antioxidant potential. However, decreased photosynthetic efficiency and a $20 \%$ yield reduction per plant, which corresponded on average to $223 \mathrm{~g}$ of fruit, were observed. Considering the mass balance of fruit yield and phenolic concentration, phenolic content was more than $20 \%$ higher in treated fruit, which compensated for the yield 
334

335

336

337

338

339

340

341

342

343

344

345

346

347

348

349

350

351

352

353

354

355

356

357

reduction. Furthermore, UV-C radiation applied during strawberry cultivation decreased greenhouse spore count and spontaneous development of Botrytis cinerea in fruit postharvest.

\section{Acknowledgements}

The authors would like to thank Caroline Garcia and Rosaria Azambuja for their skillful technical assistance and CAPES-Cofecub-INRA (2013), CNPq (306771/2014-4; 441856/2014-4), and Fapergs (11/0733-0) for financial support for research.

\section{References}

Amil-Ruiz, F., Blanco-Portales, R., Muñoz-Blanco, J., Caballero, J.L., 2011. The strawberry plant defense mechanism: a molecular review. Plant Cell Physiol. 52, 1873-1903.

Barrios, S., Lema, P., Lareo, C., 2014. Modeling respiration rate on strawberry (cv. San Andreas) for modified atmosphere packaging design. Int. J. Food Prop. 17, 2039-2051.

Bekaert, S., Storozhenko, S., Mehrshahi, P., Bennett, M. J., Lambert, W., Gregory III, J.F., Schubert, K., Hugenholtz, J., Straeten, D.V.D., Hanson, A.D., 2008. Folate biofortification in food plants. Trends Plant Sci. 13, 1360-1385.

Booij-James, I. S., Dube, S. K., Jansen, M. A. K., Edelman, M., Mattoo, A. K., 2000. Ultraviolet-B radiation impacts light-mediated turnover of the photosystem II reaction center heterodimer in Arabidopsis mutants altered in phenolic metabolism. Plant Physiol. 124, 12751283. 
Baka, M., Mercier, R., Corcuff, F., Castaigne, F., Arul, J., 1999. Photochemical treatment to improve storability of fresh strawberries. J. Food. Sci. 64, 1068-1072.

Cantu, D., Vicente, A.R., Labavitch, J.M., Bennett, A.B., Powell, A.L.T., 2008. Strangers in the matrix: plant cell walls and pathogen susceptibility. Trends Plant Sci. 13, 610-617.

Charles, M. T., Mercier, J., Makhlouf, J., Arul, J., 2008. Physiological basis of UV-C induced

resistance to Botrytis cinerea in tomato fruit. I. Role of pre and post-challenge accumulation of the phytoalexin rishitin. Postharvest Biol. Technol. 47, 10-20. (a)

368

Charles, M.T., Maklouf, J., Arul, J., 2008. Physiological basis of UV-C induced resistance to

Botrytis cinerea in tomato fruit. II. Modification of fruit surface and changes in fungal colonization. Postharvest Biol. Technol. 47, 21-26. (b)

372

Charles, M.T., Goulet, A., Arul, J. 2008. Physiological basis of UV-C induced resistance to

Botrytis cinerea in tomato fruit. IV. Biochemical modification of structural barriers.

Postharvest Biol. Technol. 47, 41-53. (c)

377 Chen, L., Jia, H., Tian, Q., Du, L., Gao, Y., Miao, X., Liu, Y., 2012. Protecting effect of phosphorylation on oxidative damage of D1 protein by down-regulating the production of 148. 
382

383

384

385

386

387

388

389

390

391

392

393

394

395

396

397

398

399

400

401

402

403

404

Delchier, N., Reich, M., Renard, C.M.G.C., 2012. Impact of cooking methods on ascorbic acid and lutein in green beans (Phaseolus vulgaris) and spinach (Spinacea oleracea). LWTFood Sci. Technol. 49, 197-201.

Feliziani, E., Landi, L., Romanazzi, G., 2015. Preharvest treatments with chitosan and other alternatives to conventional fungicides to control postharvest decay of strawberry. Carbohyd. Polym. 132, 111-117.

Galli, V., Borowski, J.M., Perin, E.C., Messias, R.S., Labonde, J., Pereira, I.S., Anjos, S.D., Rombaldi, C.V., 2014. Validation of reference genes for accurate normalization of gene expression for real-time-quantitative PCR in strawberry fruits using different cultivars and osmotic stresses. Gene. 554, 205-214.

Giampieri, F., Forbes-Hernandes, T.Y., Gasparini, M., Alvarez-Suarez, J.M., Afrin, S., Bompadre, S., Quiles, J.L., Mezzetti, B., Battino, M., 2015. Strawberry as a health promoter: an evidence based review. Food Funct. 6, 1386-1398.

Gill, S.S., Tuteja, N., 2010. Reactive oxygen species and antioxidant machinery in abiotic stress tolerance in crop plants. Plant Physiol. Biochem. 48, 909-930.

Goltsev, V., Zaharieva, I., Chernev, P., Strasser, R.J., 2009. Delayed fluorescence in photosynthesis. Photosyn. Res. 101, 217-232.

Comment citer ce document 
405

406

407

408

409

410

411

412

413

414

415

416

417

418

419

420

421

422

423

424

425

426

427

428

429

González-Aguilar, G.A., Villegas-Ochoa, M.A., Martínez-Téllez, M.A., Gardea, A.A., AyalaZavala, J.F., 2007. Improving antioxidant capacity of fresh-cut mangoes treated with UV-C. J. Food Sci. 72, 197-202.

Gurunani, M.A., Venkatesh, J., Tran, L.S.P., 2015. Regulation of photosynthesis during abiotic stress-induced photoinhibition. Mol Plant.8, 1-17.

Guidarelli, M.C., Mourgues, F., Perrotta, G., Rosati, C., Bertolini, P., 2011. Colletotrichum acutatum interactions with unripe and ripe strawberry fruits and differential responses at histological and transcriptional levels. Plant Pathol. 60, 685-697.

Hüther, C.M., Ramm, A., Rombaldi, C.V., Bacarin, M.B., 2013. Physiological response to heat stress of tomato-Micro-Tom plants expressing high and low levels of mitochondrial sHSP23.6 protein. Plant Growth Regul. 70, 175-185.

Kadir, S., Sidhu, G., 2006. Strawberry (Fragaria $x$ ananasa Duch.) growth and productivity as affected by temperature. Hort Sci. 41, 1423-1430.

Lemoine, M.L., Chaves, A.R., Martínez, G.A., 2010. Influence of combined got air and UV-C treatment on the antioxidant system of minimally processed broccoli (Brassica oleracea L. var. Italica). LWT- Food Sci. Technol. 43, 1313-1319.

Lewers, K.S., Maas, J.L., Hokanson, S.C., Gouin, C., Hartung, J.S., 2003. Inheritance of resistance in strawberry to bacterial angular leaf spot disease caused by Xanthomonas fragarie. J. Amer. Soc. Hort. Sci. 128, 209-212. 
430

431

432

433

434

435

436

437

438

439

440

441

442

443

444

445

446

447

448

449

450 Portela, I.P., Peil, R.M.N., Rombaldi, C.V., 2012. Effect of nutrient concentration on growth, 451

452

Maharaj, R., Arul, J., Nadeau, P., 1999. Effect of photochemical treatment in the preservation of fresh tomato (Lycopersicum esculentum cv. Capello) by delaying senescence. Postharvest Biol. Technol. 15, 13-23.

Mazzucotelli, E., Mastrangelo, A.M., Crosatti, C., Guerra, D., Stanca, M., Cattivelli, L., 2008. Abiotic stress response in plants: when post-transcriptional and post-translational regulations control transcription. Plant Sci. 174, 420-431.

Neri, F., Cappellin, L., Spadoni, A., Alarcon, A.A., Aprea, E., Romano, A., Gasperi, F., Biasioli, F., 2014. Role of strawberry volatile organic compounds in the development of Botrytis cinerea infection. Plant Pathol. 64, 709-717.

Obande, M.A., Tucker, G.A., Shama, G., 2011. Effect of preharvest UV-C treatment of tomatoes (Solanum lycopersicon Mill.) on ripening and pathogen resistance. Postharvest Biol. Technol. 62, 188-192.

Pombo, M.A., Rosli, H.G., Martinez, G.A., Civello, P.M., 2011. UV-C treatment affects the expression and activity of defense genes in strawberry fruit (Fragaria x ananassa, Duch.). Postharvest Biol. Technol. 59, 94-102.

\footnotetext{
yield and quality of strawberries in hydroponic system. Hort. Brasil. 30, 266-273.
} 
453 Severo, J., Tiecher, A., Pirrello, J., Regad, F., Latché, A., Pech, J.C., Bouzayen, M., 454 Rombaldi, C.V., 2015. UV-C radiation modifies the ripening and accumulation of ethylene 455 response factor (ERF) transcripts in tomato fruit. Postharvest Biol. Technol. 102, 9-16. (a)

456

457 Severo, J., de Oliveira, I.R., Tiecher, A., Chaves, F.C., Rombaldi, C.V., 2015. Postharvest 458 UV-C treatment increases bioactive, ester volatile compounds and a putative allergenic 459 protein in strawberry. LWT-Food Sci. Technol. 64, 685-692. (b)

460

461 Sonneveld, C., Straver, N., 1999. Nutrient solutions for vegetables and flowers grown in 462 water or substrates, 10 th ed. Naaldwijk. Holland.

463

464 Stevens, R., Buret, M., Garchery, C., Carretero, Y., Causse, M., 2006. Technique for rapid small-scale analysis of vitamin C levels in fruit and application to a tomato mutant collection. J. Agric. Food Chem. 54, 6159-6165.

467

Tikkanen, M., Gollan, P.J., Mekala, N.R., Isojarvi, J., Aro, E.M., 2014. Light-harvesting 469 mutants show differential gene expression upon shift to high light as a consequence of photosynthetic redox and reactive oxygen species metabolism. Phil. Trans. R. Soc. B. 369, 20130229.

473 Topcu, Y., Dogan, A., Kasimoglu, Z., Sahin-Nadeem, H., Erkan, M., 2015. The effects of UV 474 radiation during the vegetative period on antioxidant compounds and postharvest quality of broccoli (Brassica oleraceae L.). Plant Physiol. Biochem. 93, 56-65. 
477 Tulipani, S., Marzban, G., Herndl, A., Laimer, M., Mezzetti, B., Battino, M., 2011. Influence 478 of environmental and genetic factors on health-related compounds in strawberry. Food Chem. $479124,906-913$.

480

481 Xie, Z., Charles, M.T., Fan, J., Charlebois, D., Khanizadeh, S., Rolland, D., Roussel, D., 482 Deschênesa, M., Dubé, C., 2015. Effects of preharvest ultraviolet-C irradiation on fruit 483 phytochemical profiles and antioxidant capacity in three strawberry (Fragaria $x$ ananassa 484 Duch.) cultivars. J. Sci. Food Agric. 95, 2996-3002.

Xie, Y., Xu, D., Cui, W., Shen, C., 2012. Mutation of Arabidopsis HY1 causes UV-C 487 hypersensitivity by impairing carotenoid and flavonoid biosynthesis and the down-regulation of antioxidant defense. J. Exp. Bot. 63, 3869-3884.

489

Xu, Y.H., Liu, R., Yan, L., Liu, Z.Q., Jiang, S.C., Shen, Y.Y., Zhang, D.P., 2012. Lightharvesting chlorophyll a/b-binding proteins are required for stomatal response to abscisic acid 492 in Arabidopsis. J. Exp. Bot. 63, 1095-1106.

493

Zivcak, M., Brestic, M., Govindjee, H.M.K., 2014. Photosynthetic responses of sun-and shade-grown barley leaves to high light: is the lower PSII connectivity in shade leaves associated with protection against excess of light? Photosyn. Res. 119, 339-354.

Zucker, M., 1965. Induction of phenylalanine deaminase by light and its relation to chlorogenic acid synthesis in potato tuber tissue. Plant Physiol. 40, 779-785. 
Fig. 1. Experiment timeline with crop cycle (days after transplanting) and sampling times

501 - UV-C applications, ( ) - photosynthetic measurements, $(\bullet)$ - physicochemical and enzyme

502 activity determinations (highest productivity period), (1) - microorganism occurrence, $(\boldsymbol{\square})-$

503 qPCR and dates for determination of fungal inocula in the air, and ( ) - dry matter 504 partitioning determination.

505

506 Fig. 2. Effect of preharvest UV-C treatment on $\mathrm{CO}_{2}$ assimilation rate (A), stomatal 507 conductance (B), intracellular $\mathrm{CO}_{2}$ (C), fluorescence (D), quantum yield efficiency of 508 photosystem II $(F v / F m)(E)$, dry matter partitioning $(\mathrm{F})$, fruit yield per plant $(\mathrm{G})$ and total 509 yield $(\mathrm{H})$ in control $(\bullet-; \square)$ and UV-C treated fruit $(\cdots, \cdots ; \square)$. Asterisks indicate 510 level of significance at $\mathrm{P} \leq 0.05$. Vertical bars indicate standard deviation.

512 Fig. 3. Occurrence of fungi in the air (A), number of mesophilic microorganisms (B), 513 incidence of fungal decay without inoculation with Botrytis cinerea spores (C), incidence of 514 fungal decay with inoculation of $10^{4}$ Botrytis cinerea spores (D) in Control strawberry ( $\longrightarrow-$ $515 ; \quad$ ) and UV-C treated fruit $(\cdots, \cdots ; \square)$. Asterisks indicate level of significance at $\mathrm{P} \leq 0.05$. 516 Vertical bars indicate standard deviation.

518 Fig. 4. Phenylalanine ammonia lyase (PAL) activity (A), total phenolic content (B), total 519 anthocyanin content (C), ascorbic acid content (D), antioxidant activity (E) and folate content ). Asterisks indicate level of significance at $\mathrm{P} \leq 0.05$. Vertical bars indicate standard deviation.

523 Fig. 5. Relative transcript accumulation of genes encoding enzymes associated with 524 photosynthesis, resistance to pathogens, phenolic compounds biosynthesis and L-ascorbic 
525 acid biosynthesis in leaves of control strawberries and UV-C treated fruit. Samples were

526 collected at $0,8,32,56$, and $80 \mathrm{~d}$ after treatment. Leaves and fruit collected from control

527 strawberries plants were used as baseline expression to establish the relative transcript 528 accumulation. Values were normalized by applying $\log 2$. Transcript accumulation is 529 represented in Multi Experiment Viewer software (TIGR MeV). Green color on the left 530 represents the minimum expression level, black color in the middle represents the median 531 level and red color represents the maximum transcription level observed. 


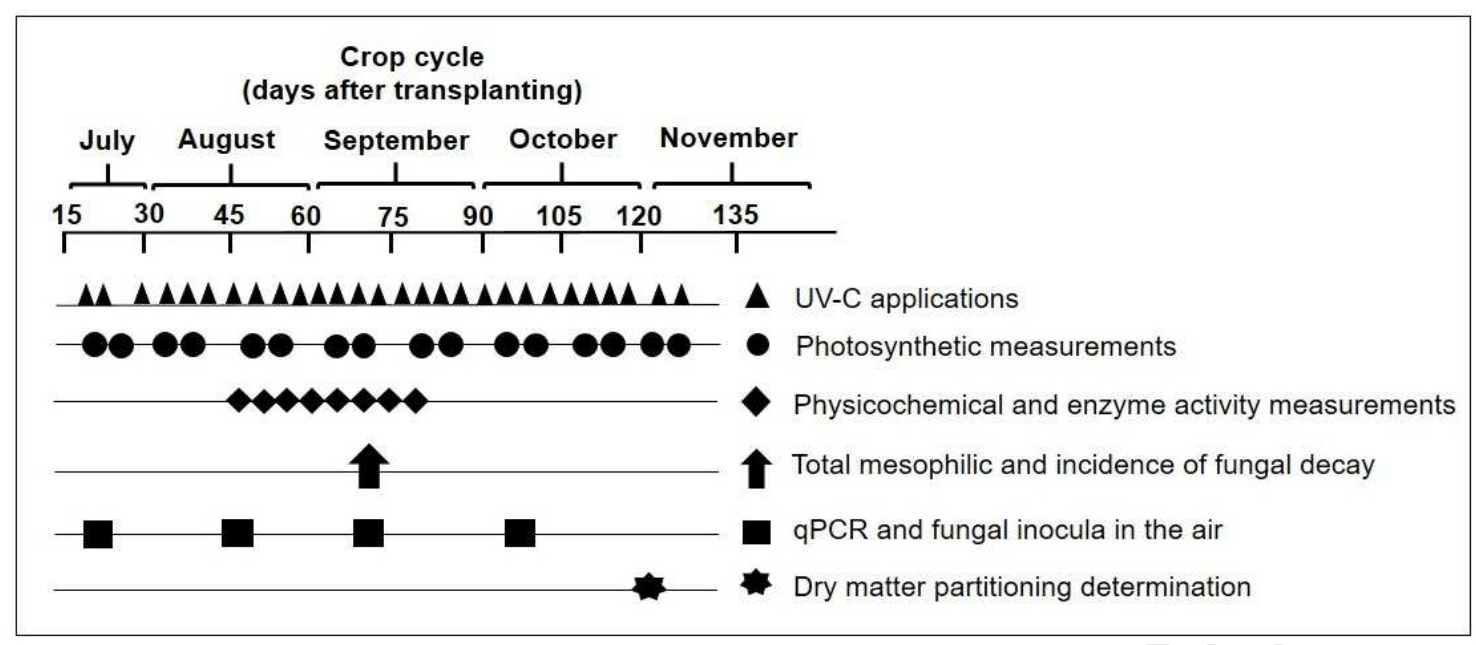

Fig. 1. Experiment timeline with crop cycle (days after transplanting) and sampling times $(\boldsymbol{\Delta})$ - UV-C applications, (O) - photosynthetic measurements, $(\bullet)-$ physicochemical and enzyme activity determinations (highest productivity period), ( $\mathbf{U})$ - microorganism occurrence, ( $\boldsymbol{\square}$ ) - qPCR and dates for determination of fungal inocula in the air, and ( ) - dry matter partitioning determination. 

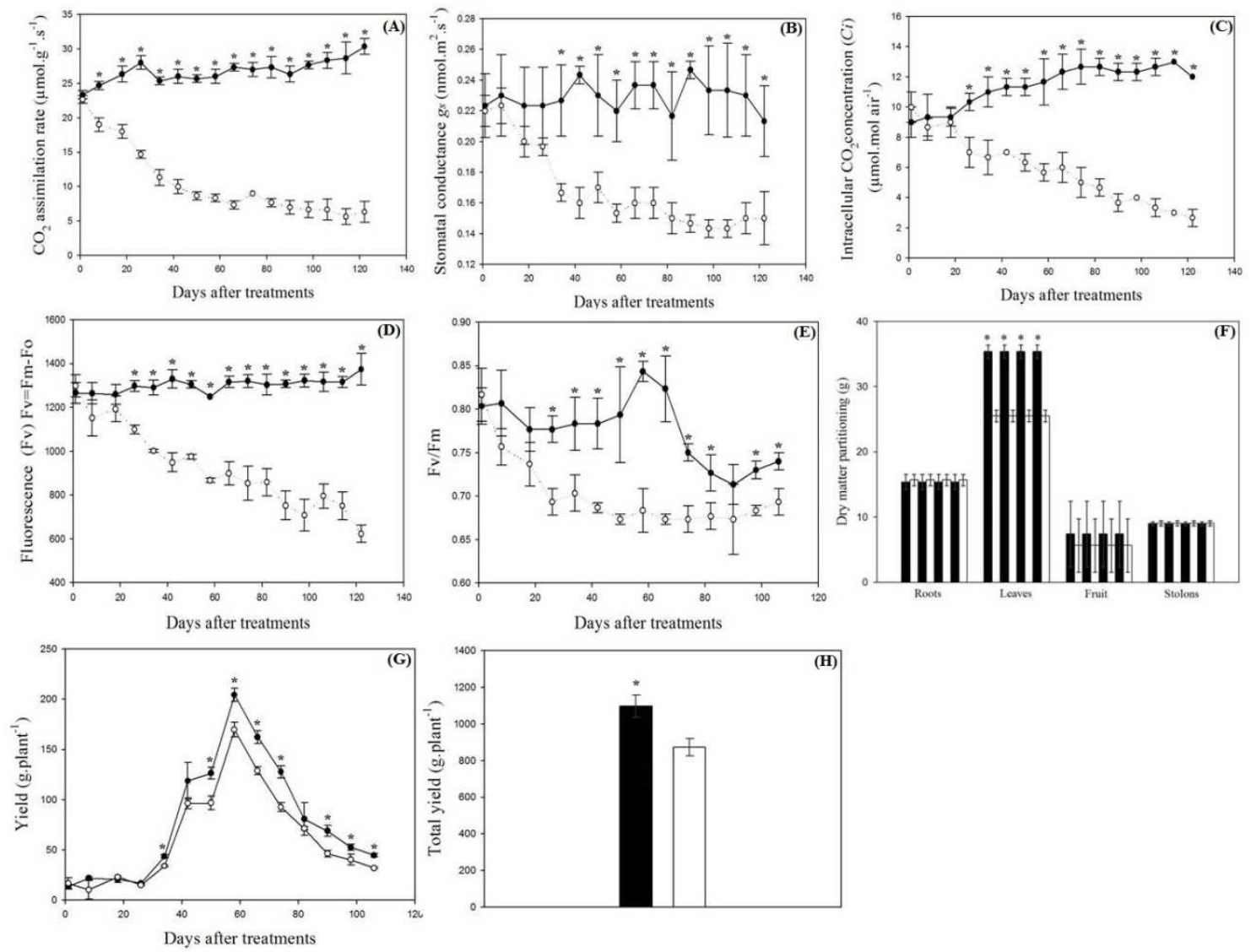

Fig. 2. Effect of preharvest $\mathrm{UV}-\mathrm{C}$ treatment on $\mathrm{CO}_{2}$ assimilation rate (A), stomatal conductance (B), intracellular $\mathrm{CO}_{2}$ (C), variable fluorescence (D), quantum yield efficiency of photosystem II $(F v / F m)(E)$, dry matter partitioning $(F)$, fruit yield per plant $(\mathrm{G})$, and total yield $(\mathrm{H})$ in control $(-\bullet ;-)$ and UV-C treated fruit $(\cdots \circ \cdots$; ). Asterisks indicate level of significance at $\mathrm{P} \leq 0.05$. Vertical bars indicate standard deviation. 

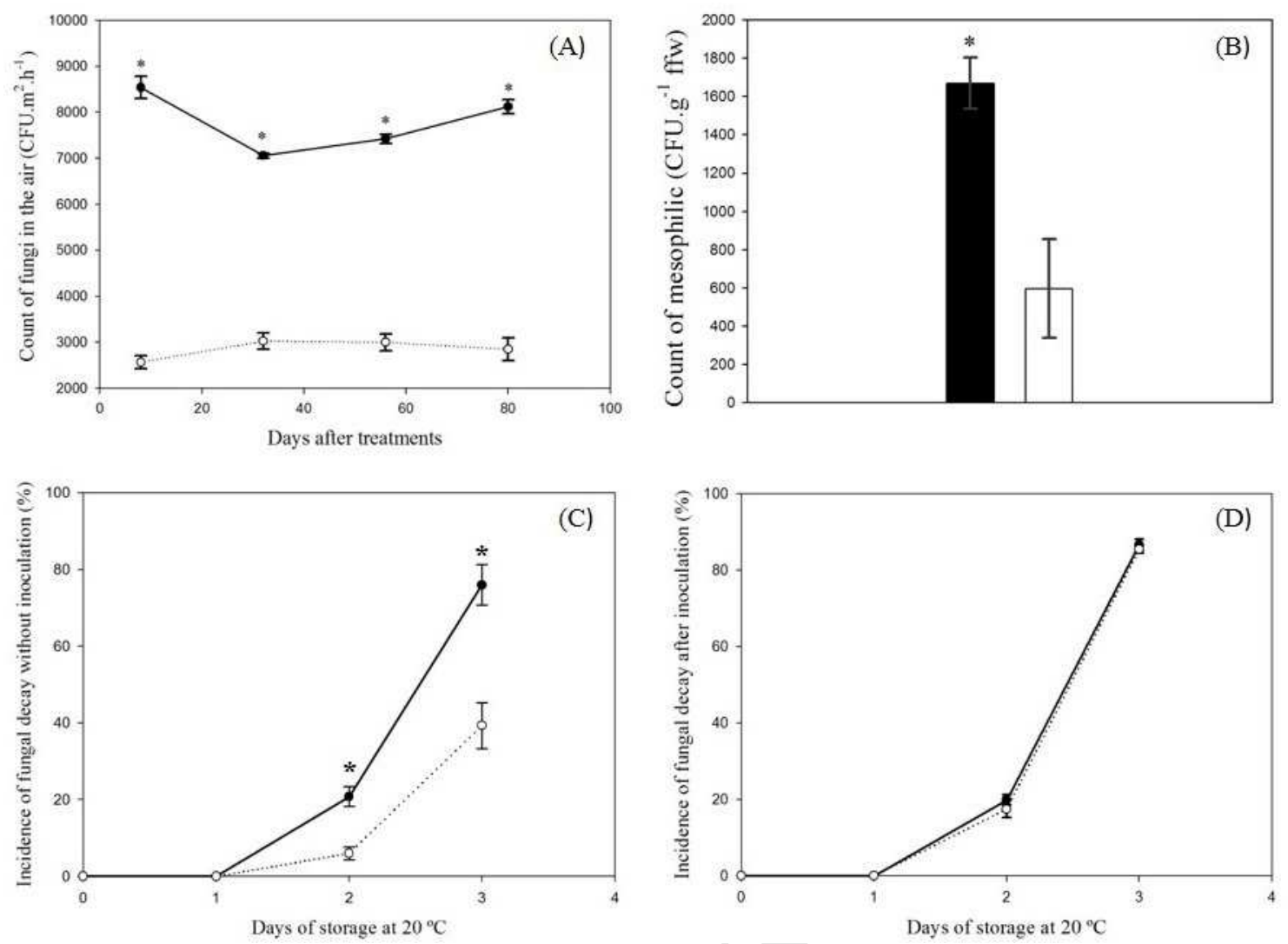

Fig. 3. Occurrence of fungi in the air (A), number of mesophilic microorganisms (B), incidence of fungal decay without inoculation with Botrytis cinerea spores (C), incidence of fungal decay with inoculation of $10^{4}$ Botrytis cinerea spores (D) in Control strawberry $(-\bullet ; \square)$ and UV-C treated fruit $(\cdots, \cdots ; \square)$. Asterisks indicate level of significance at $\mathrm{P} \leq 0.05$. Vertical bars indicate standard deviation. 

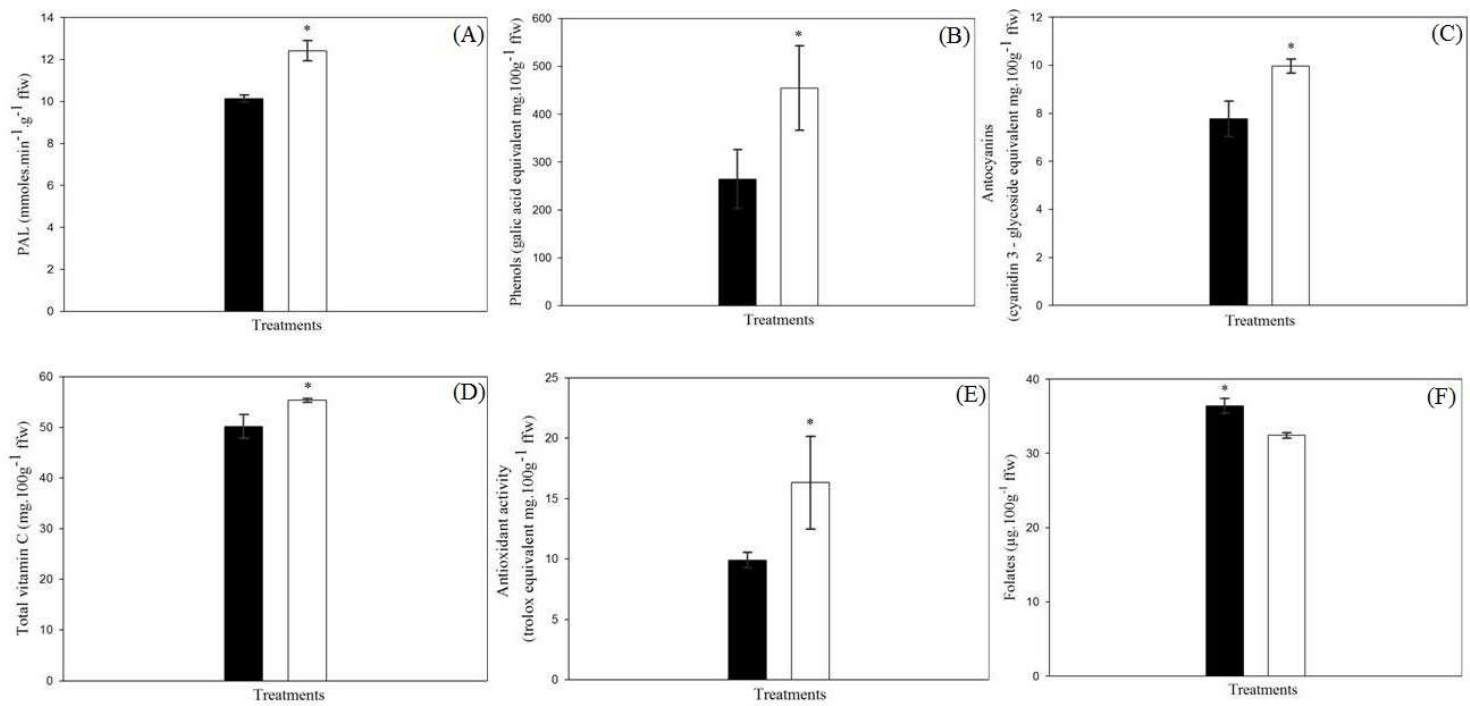

Fig. 4. Phenylalanine ammonia lyase (PAL) activity (A), total phenolic content (B), total anthocyanin content (C), ascorbic acid content (D), antioxidant activity (E) and folate content (F) in Control strawberry and UV-C treated fruit ). Asterisks indicate level of significance at $\mathrm{P} \leq 0.05$. Vertical bars indicate standard deviation. 


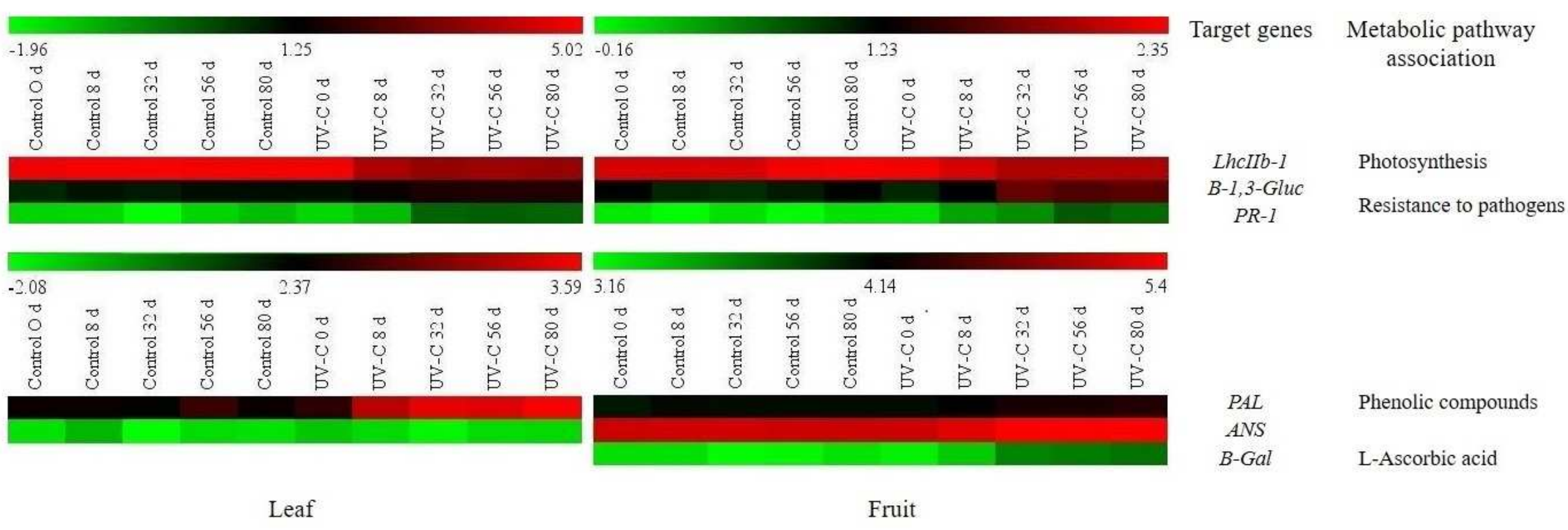

Fig. 5. Relative transcript accumulation of genes encoding enzymes associated with photosynthesis, resistance to pathogens, phenolic compounds biosynthesis and L-ascorbic acid biosynthesis in leaves of control strawberries and UV-C treated fruit. Samples were collected at 0, 8, 32, 56, and $80 \mathrm{~d}$ after treatment. Leaves and fruit collected from control strawberries plants were used as baseline expression to establish the relative transcript accumulation. Values were normalized by applying log2. Transcript accumulation is represented in Multi Experiment Viewer software (TIGR MeV). Green color on the left represents the minimum expression level, black color in the middle represents the median level and red color represents the maximum transcription level observed. 
Photosynthetic efficiency and light harvest complex mRNA accumulation were down regulated by UV-C

Preharvest UV-C lowered yields and reduced leaf dry matter content

Preharvest UV-C promoted antioxidant metabolism activation and prevented fruit decay 


\section{Contribution}

All authors designed research, conducted experiments and analyzed data. Cesar Valmor Rombaldi, Fabio Clasen Chaves and Catherine Renard contributed for reagents and analytical tools. All authors wrote, read and approved the manuscript. 